исвітлено головні дослідницькі здобутки вид тного укр їнського п леогеогр ф , геоморфолог , геолог проф. . олянського. ро н лізов но вплив його н укових ідей н розвиток суч сних геоморфології і п леогеогр фії в кр їні. н чну ув гу приділено вивченню лесів т розвитку тер сових рівнів н терен х ридністер'я. озглянуто результ ти п леогеогр фічних, геоморфологічних, рхеологічних, тектонічних досліджень цього регіону нинішніми дослідник ми. оловно, ці результ ти - розвиток ідей . олянського.

лючові слов : н дз пл вн тер с, лювій, леси, викопні грунти, зледеніння, геологогеоморфологічні дослідження, плейстоцен, п леоліт, ністер, олино- оділля.

ілеспрямов ні геоморфологічні т п леогеогр фічні дослідження території кр їни поч ли проводити ще н прикінці ст., хоч , звісно, спор дично деякі дотичні геолого-геогр фічні спекти висвітлюв ли й у пр цях $\mathrm{p}$ ніших дослідниківприродозн вців. р диційно одні з перших польових геологічних н укових вивчень укр їнських теренів пов’язують з іменем російського дослідник . рбот -де- рні. ін ще 1872 р. опублікув в пр цю [1], у якій опис в результ ти геологічних досліджень уздовж лінії з лізниці, що її в той ч с будув ли між иєвом і лтою, т гілкою цієї з лізниці у н прямі н олочиськ, т кож н суміжних ділянк х. годом т кі дослідження н був ли спеці льного х р ктеру. ими почин ли з йм тися н уковці з відповідною освітою т певним кв ліфік ційним рівнем.

осить перспективним, н віть ет лонним, у пл ні геолого-геоморфологічного вивчення є р йон ридністерського оділля н д ністром.

ридністерське оділля - досить різном нітний т цік вий і водноч с н дзвич йно скл дний 3 геоморфологічного погляду $\mathrm{p}$ йон. сторія вивчення геологогеоморфологічної будови долини ністр, зокрем, генезису т віку його тер с - 3 вд ння нелегке. г то вчених, і не лише укр їнських, досліджув ло ці пит ння. дне 3 чільних місць посід ють пр ці визн чного укр їнського п леогеогр ф, геоморфолог , рхеолог рія олянського, який чи не вперше викон в комплексне і глибоке дослідження цього б г тогр нного геоморфологічного регіону кр їни. чений вивч в геологічну будову, тер совий комплекс, стр тигр фію плейстоценових відкл дів долини ністр, т кож досліджув в д вні рхеологічні культури, носії яких з селяли цю територію в п леоліті т н ступних епох х. ого н укові ідеї здобули под льший розвиток у дослідженнях прийдешніх поколінь н уковців, які вивч ли й продовжують кти-

(C) оменюк ., 2012 
вно вивч ти геолого-геоморфологічну будову цього регіону $[2,14-18,20,23,40$, $41,44]$.

х р ктеризуємо дет льніше головні н прями, у яких ідеї олянського відігр ли в гому роль.

еоморфологія. дним із центр льних пит нь під ч с геоморфологічних досліджень у р йоні лицького ридністер'я, без сумніву, бул іє проблем геоморфологічної будови долини ністр . ьогодні вв ж ють, що тер совий комплекс річки т ї̈ к рп тських приток предст влений шістьм н дз пл вними тер с ми еоплейстоценголоценового віку. межиріччі ністр - орони т кож збереглися фр гменти верхньопліоценової сьомої тер си [14-18, 20, 40, 44].

ослідження річкових тер с з вжди було принципово в жливим з вд нням під ч с проведення геоморфологічних т п леогеогр фічних досліджень з декількох причин, зокрем :

) тер си пов'язують усі різном нітні континент льні відкл ди, що виник ють одноч сно н зН чних відст нях;

б) люві льні відкл ди тер с є основним з собом стр тигр фічного зіст влення розрізів континент льних плейстоценових відкл дів, що з ляг ють д леко один від одного і різко відрізняються з генезисом і умов ми з ляг ння;

в) виявлені під ч с зіст влення зв'язки між відкл д ми д ють змогу реконструюв ти фізико-геогр фічні умови ч су їхнього н копичення;

г) річкові тер си є індик тор ми колив нь клім ту, тектонічних рухів [38].

ет льний н ліз відомих сьогодні в геологічній т геоморфологічній н уці підходів до розуміння термін “тер с" в жливий з огляду н кінцеву мету вивчення річкових тер с - їхню кореляцію 3 морфологічним, морфометричним, генетичним і віковим критеріями.

прикл д, донед вн у дослідженні тер с долини ністр ф ктично головним був морфологічний критерій, тобто кореляцію тер с проводили 3 їхньою висотою бо відносним розт шув нням тер сового рівня (порядковим номером). ічкову тер су розгляд ли тільки як форму рельєфу суч сної річкової долини, тобто рівну бо сл бко н хилену поверхню, витягнуту вздовж долини й обмежену крутим спуском до нижчого рівня і підйомом до вищого. дн к висот тер си, їі порядковий номер з леж ть від 6 г тьох чинників, у тому числі й місцевих. ому дефекти морфометричного критерію н дзвич йно великі, суто морфометричний метод веде до н перед очевидної помилки, особливо у меж х т ких тектонічно скл дних, ктивних р йонів, як ередк рп ття, оділля.

ме т ких підходів свого ч су дотримув вся і . олянський. ослідженнями в лицькому ридністер'ї він з кл в основи для под льшого вирішення б г тьох н укових проблем, які й сьогодні цік влять н уковців [35, с. 340-356]. им п че, пр цюючи н поч тк х розвою геоморфологічної н уки, коли відбув вся процес ст новлення і впров дження в пр ктику теоретико-методичних підв лин т принципів дослідження, він не м в змоги оперув ти тим спектром уст лених н укових методів т методик, які н суч сному ет пі використовують учені.

г то в чому . олянський був першопрохідцем, його стежин н укового пізн ння ще не бул протопт н, і тому не $з$ вжди його припущення, міркув ння т результ ти досліджень виявлялися пр вильними. ого метод визн чення віку тер с лише 3 лесовими покрив ми без ур хув ння їхньої висоти призвів до того, що висновки щодо віку i нумер ції тер с не з вжди пр вильні. н чно в жливіше, що 
. олянський у будові тер с чітко розрізняв вл сне люві льну й покривну ч стини, вб ч вши, що поверхи лесу допоможуть з'ясув ти пит ння віку тер с.

голосимо н головних досягненнях вченого у вивченні тер с ністр , які н були под льшого розвитку в дослідженнях його послідовників, с ме:

- скл в схему геоморфологічної будови долини ністр , як не втр тил кту льності й сьогодні; зокрем , з стосув в комплексний підхід у морфологічному описі тер с, який і досі н лежно не опр цьов ний, т кож використ в нові методи вивчення віку т поширення річкових тер с;

- уперше помітив різницю між двом н йд внішими і н йвищими тер с ми ністр , які до того ч су прийм ли з одну. ьому сприяло те, що морфологічно суч сні шост і сьом тер си ближче одн до одної, ніж до решти тер с ністр . они з йм ють смугу пл то, що примик є до долини ністр (шост тер с . олянського, суч сн сьом ), і брівку долини (п'ят тер с . олянського, суч сн шост ), тоді як молодші тер си розт шов ні н іiї схил х (т бл. 1);

блиця 1

оменкл тур тер с ністр у середній течії з д ними різних дослідників

\begin{tabular}{|c|c|c|c|c|c|}
\hline \multirow[b]{2}{*}{ 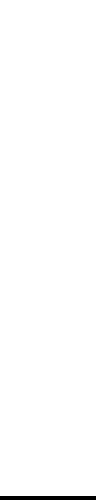 } & \multicolumn{3}{|c|}{ ідносні висоти поверхонь тер с ністр } & \multirow[b]{2}{*}{ 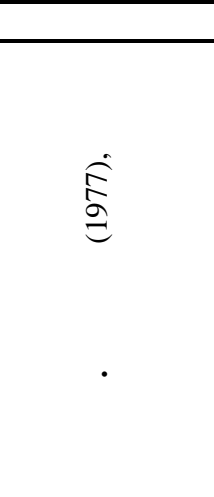 } & \multirow[b]{2}{*}{ 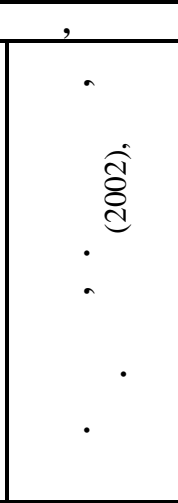 } \\
\hline & 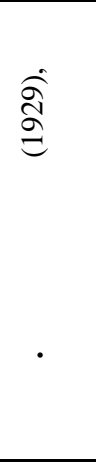 & 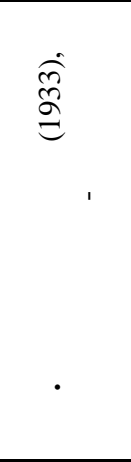 & 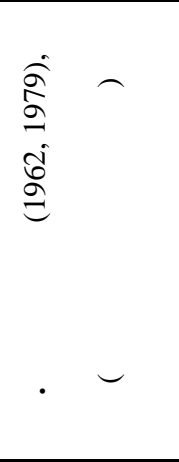 & & \\
\hline ерш & 4 & $5-7$ & $4-6$ & $10-15$ & $4-11$ \\
\hline руг & 4 & \multirow{2}{*}{ 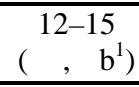 } & 10 & $25-40$ & $12-15$ \\
\hline ретя & 10 & & 20 & $45-60$ & $20-25$ \\
\hline етверт & $80-90$ & $45-50$ & $35-50$ & $70-85$ & $35-45$ \\
\hline 'ят & 100 & $85-90$ & $70-80$ & $105-120$ & $70-80$ \\
\hline ост & 150 & $140-150$ & $110-120$ & $145-155$ & $90-100$ \\
\hline ьом & & $175-200$ & $140-160$ & $170-180$ & $140-150$ \\
\hline осьм & & & & $220-230$ & \\
\hline
\end{tabular}

- відокремлюв в к ньйонну і н дк ньойонну історію розвитку долини ністр , 3 вдяки чому диференціюв в тер си н н ддолинні (шост і п’ят тер си у розумінні

1 . иржиківський після озн йомлення з результ т ми досліджень . олянського в лицькому ридністер'ї змінив нумер цію тер с ністр н ділянці огилів- одільський- мпіль т к: тер си . иржиківського і b з відносними висот ми і генезисом відповід ють другій і третій тер с м . олянського. ому . иржиківський пис в: “ ілком в згоді з . олянським я д лі, в інших своїх пр цях зв тиму свою тер су другою, тер су b-третьою тер сою” [12, c. 164]. 
. олянського, п’ят утворює брівку к ньйоноподібної долини ністр ) т долинні (перш -четверт);

- з'ясув в, що в чистому вигляді, без домішки х р ктерної для з хідної ч стини оділля породи - червоного нижньодевонського пісковику, к рп тськ г льк тр пляється тільки у відкл д х н йд внішої тер си. н ступній, молодшій тер сі девонський пісковик уже є (що з лежить від більшої глибини ерозійного врізу) [14, с. 80];

- розрізняв цокольну (корінну) і н сипну ч стини тер си;

- розвив в прогресивну ідею з лучення покривних лесово-грунтових товщ тер с до вирішення проблеми ч су їхнього формув ння і поширення (для долини ністр ); в жливе місце відводив пит нням з ляг ння різновікових лесів н тер с х (теорія “леси і тер си”, яку сьогодні ктивно розвив ють суч сні дослідники плейстоцену оділля);

- одним з перших вир зно висвітлив зв'язок між тер с ми ністр і новітніми тектонічними рух ми в одільському ридністер'ї, н голосивши, що в плейстоцені н оділлі відбулися дв тектонічні підняття [25]. огляду н це пост ли дв ерозійні цикли. ерший цикл р нньоплейстоценового віку (перед риським, бо дніпровським, зледенінням) створив зрілі форми рельєфу вище рівня п’ятої тер си в розумінні . олянського. ругий ерозійний цикл відбув вся у пізньому плейстоцені, точніше в ост нню міжльодовикову епоху (рис-вюрм , микулинський інтергляці л), і створив нижче рівня його п'ятої тер си молоді яружні форми рельєфу.

p ндіозний ф ктичний м тері л, зібр ний . олянським протягом 1923-1929 pp. $[25,27-28,30,45-48,52]$, який ст в основою всебічного т глибокого моногр фічного дослідження “ одільські етюди: тер си, леси т морфольогія лицького оділля н д ністром”, не втр тив кту льності й досі. ур хув нням кореляції схем геоморфологічної будови долини ріки з д ними суч сних дослідників його й тепер використовують для под льшого широкого дослідження тер с подільської ділянки долини ністр , оскільки він відкрив є нові можливості у вивченні пит нь геолого-геоморфологічної будови цієї території перед нинішніми н уковцями з різних г лузей природничої н уки.

ьогодні н йточнішим критерієм зіст влення тер с ув ж ють комплексний генетико-віковий (стр тигр фічний) [41, с. 130]. ічкову тер су розгляд ють як слід певного історико-геологічного ет пу розвитку річкової долини, з фіксов ного бо у рельєфі, бо у відкл д $\mathrm{x}$, бо і в тому, і в іншому (з . уб ковим). ічков тер с як історикогеологічне утворення є $з$ лишком д внього $з$ пл вного лож долини, з відкл д ми бо без них, вир жене у рельєфі бо похов не під товщею молодших відкл дів.

ей критерій, н думку суч сних дослідників, д є добрі м тері ли для хронологічного впорядкув ння процесів ерозії, кумуляції і, врешті-решт, виявлення основних ет пів формув ння тер сового комплексу річки. кий підхід потребує розділення досліджув них тер с н одиниці, прид тні для стр тигр фічної кореляції.

меж $\mathrm{x}$ кр їни м йже всі тер си прямо бо опосередков но зіст влені з різними зледеніннями чи їхніми ст діями. прикл д, тер си ністр у схем х . еклич , . офштейн зіст влені з головними п леогеогр фічними (п леоклім тичними) ет п ми $[6,8-10,14]$. икористовують твердження про те, що льодовиковим епох м відповід $€$ кумуляція лювію у річкових долин $\mathrm{x}$, міжльодовиковим - посилення ерозії т вироблення уступів, які відмежовують одну тер су від іншої. дн к сьогодні поряд $з$ ідеєю виріш льного впливу колив нь клім ту н процеси ерозії т кумуляції існують інші припущення, зокрем , рухи земної кори і колив ння 6 зису ерозії. ступи, що відділяють сусідні тер си, не можн тлум чити як межі стр тигр фічних горизонтів. 
нші труднощі, що виник ють під ч с вивчення геоморфологічної будови долини ністр, пов'яз ні з тим, що у долині ністр н явності тер сових сходинок, перекритих лювієм, ч сто недост тньо для виділення тієї чи іншої тер си. е пов'яз но з ухилом тер с униз з течією, у цьому р зі ухили різновікових тер с є різними, т кож переходом деяких з них у похов ний ст н, тектонічними деформ ціями поверхонь тер с тощо.

ьогодні бсолютно впевнено можн говорити лише про те, що стр тигр фічним еквів лентом будь-якого зледеніння (гляці лу) є лесовий горизонт, еквів лентом міжльодовикового потепління (інтергляці лу) - викопний грунт. ому дет льний н ліз лесово-грунтових покривів тер с - в жлив скл дов п леогеогр фічного н лізу д вньо люві льних світ, що д є змогу говорити про вік тієї чи іншої тер си. перше т кий підхід до вивчення тер с т їхньої кореляції з пропонув в . олянський, який опис в методику цих робіт. оротко методик досліджень поляг є в т кому.

1. ронологічно молодші леси перекрив ють щор з молодші тер си.

2. ой ф кт, що хронологічно молодші леси перекрив ють молодші тер си, пов'яз ний з поглибленням долин рік оділля. цієї причини вивчення перекриття різновікових лесів н тер с х д $є$ змогу точно д тув ти плейстоценові ерозійні цикли, які відбув лися н оділлі.

3. ронологічно молодші леси вкрив ють подекуди і хронологічно ст рші тер си, одн к 3 ляг ють лише н лес х і тер с х попереднього зледеніння [30, с. 122-123].

ині н тер с х ністр опис но пр ктично всі стр тигр фічні горизонти покривної лесової товщі плейстоцену, верхньої ч стини пліоцену; виявлено х р ктерний н бір стр тигр фічних горизонтів лесової п чки для кожної тер си ністр в меж х ередк рп ття т прилеглої ч стини оділля [39, 40, 44] (див. т бл. 2).

тже, згідно з д ними, отрим ними під ч с опр цюв ння покривних лесовогрунтових товщ тер с ністр . огуцьким т . цишиним, вік шостої тер си (тер си у гвізді) - еоплейстоцен, п’ятої (г лицької) - лубенський інтергляці л, окський гляціл (нижній плейстоцен), четвертої (м ріямпільської) - коршівський (одинцовський) інтергляці л (середній плейстоцен), третьої (єзупільської) - московський гляці л, другої (колодіївської) - горохівський (микулинський) інтергляці л, першої тер си, бо високої з пл ви - післяльодовиковий ч с (голоцен) [41, с. 133-134]. н шу думку, вік другої і п'ятої тер с ністр потребує довивчення й уточнення.

леогеогр фія плейстоцену. пр ці [36, с. 342-363] вторк розглянул історію дослідження лесових покривів олино- оділля різними вченими. окрем, зн чну ув гу приділено висвітленню н укових ідей . олянського в г лузі п леогеогр фії плейстоцену, четвертинної геології, стр тигр фії плейстоценових відкл дів олинооділля т ередк рп ття. ого внесок у розвиток геоморфологічної т п леогеогр фічної г лузей н уки в жко переоцінити, оскільки вченого по пр ву вв ж ють одним із першопрохідців у цій г лузі. укові думки . олянського були досить передовими т прогресивними і ч сто випередж ли поступ тогоч сної н уки. ін одним із перших прийняв теорію про поділ лесів н різноч сові горизонти, н д в в в жливого стр тигр фічного зн чення викопним грунт м у товщі плейстоценових відкл дів, ув ж в леси віковими н лог ми плейстоценових зледенінь, викопні грунти - н лог ми потеплінь у четвертинний період, з стосовув в комплексний підхід до вивчення лесово-грунтової серії плейстоцену н терен х ридністерського оділля. лизькі ідеї в ентр льній кр їні розвив в один із фунд торів лесової стр тигр фії . рокос [21, 22]. 
блиця 2

хем кореляції тер с ністр зі стр тигр фічними горизонт ми лесово-грунтової серії лицького ридністер'я [41, с. 133]

\begin{tabular}{|c|c|c|c|c|}
\hline \multirow{2}{*}{\multicolumn{2}{|c|}{$\begin{array}{r}\text { Г льн } \\
\text { стр ти- } \\
\text { Гр фічн } \\
\text { ШК Л }\end{array}$}} & \multirow{3}{*}{$\begin{array}{c}\text { тр тигр фічні горизонти лесово-грунтової серії } \\
\text { лицького ридністер'я }\end{array}$} & \multicolumn{2}{|c|}{$\begin{array}{c}\text { с формув ння у розрізі } \\
\text { тер си }\end{array}$} \\
\hline & & & \multirow{2}{*}{$\begin{array}{c}\text { основи покривної } \\
\text { суб ер льної } \\
\text { товщі }\end{array}$} & \multirow{2}{*}{ лювію } \\
\hline $\begin{array}{r}\text { оз- } \\
\text { ді.л }\end{array}$ & $\mathbf{K}^{\mathbf{H}-}$ & & & \\
\hline $\begin{array}{l}\frac{T}{d} \\
\stackrel{J}{0} \\
0 \\
0\end{array}$ & $\begin{array}{l}\text { T } \\
5 \\
\text { S }\end{array}$ & уч сний грунт & ершої & $\begin{array}{c}\text { пл ви, } \\
\text { першої } \\
\text { тер си }\end{array}$ \\
\hline \multirow{14}{*}{ 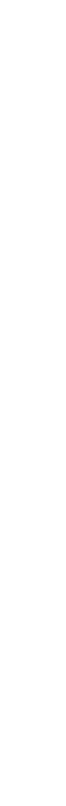 } & \multirow{4}{*}{ 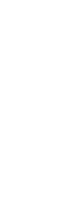 } & ерхній горизонт верхньоплейстоценових лесів & & \\
\hline & & убнівський грунт & & \\
\hline & & ижній горизонт верхньоплейстоценових лесів & & \\
\hline & & орохівський викопний грунтовий комплекс & ругої & ругої \\
\hline & \multirow{3}{*}{ 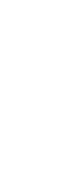 } & ерхній горизонт середньоплейстоценових лесів & ретьої & ретьої \\
\hline & & оршівський викопний грунтовий комплекс & етвертої & етвертої \\
\hline & & ижній горизонт середньоплейстоценових лесів & & \\
\hline & \multirow{7}{*}{ 焉 } & уцький викопний грунт & & \\
\hline & & ерхній горизонт нижньоплейстоценових лесів & & \\
\hline & & ок льський викопний грунт & & \\
\hline & & ижній горизонт нижньоплейстоценових лесів & \multirow{2}{*}{ 'ятої } & \multirow{2}{*}{ 'ятої } \\
\hline & & еси (глейовий горизонт) & & \\
\hline & & икопний грунтовий комплекс типу солотвин & & $\begin{array}{c}\text { ожли- } \\
\text { во, п’ятої } \\
-? \\
\end{array}$ \\
\hline & & еси (глейовий горизонт, соліфлюкційний горизонт) & & \\
\hline \multirow{2}{*}{\multicolumn{2}{|c|}{ оплейсто- }} & икопний грунтовий комплекс типу з гвіздя & остої & \\
\hline & & & & остої \\
\hline
\end{tabular}

рогресивні ідеї . олянського [36, с. 342-363] н були под льшого розвитку в пр цях інших дослідників плейстоцену кр їни, які пр цюв ли у г лузі лесової проблем тики згодом. ісля 30-х років ст. учені поч ли ктивно з луч ти лесовогрунтові покривні п чки для визн чення віку тер с. кл дено нові, прогресивніші й дет льніші стр тигр фічні схеми плейстоцену кр їни, які грунтуються н використ нні вже відомої з досліджень попередників інформ ції, проте їхній принцип стр тигр фічного розчленув ння відкл дів т кий с мий, який уперше використ в . олянський н території олино- оділля. е стр тигр фічні схеми, скл дені . огуцьким [2, 3], . огуцьким т . н нчонт [44, tab. 36-39] для території з хідної ч стини кр їни (т бл. 3); . морієм [19, т бл. 31], . онд рчуком [5, с. 24], 
. екличем [7; 8, с. $57 ; 9 ; 37$, с. 49, рис. 14] $]^{2}$ (див. т бл. 3), . ожиком [43; 44, tab. 36-39] для центр льної і східної ч стин; т кож . еличком $[11 ; 37$, с. 42-43, рис. 13 , с. 49 , рис. 14] для території вропейської осії, . рущ ком для території ольщі [44, tab. 36-39]. омплексність н укових досліджень - це один із н йв жливіших постул тів розвитку п леогеогр фії т геоморфології н суч сному ет пі. с ме вон ст новил кредо всього н укового життя - олянського ще н поч тку розвою цих н ук у першій половині ст.

чений використовув в стр тигр фічну схему поділу плейстоценових лесів, як 3 позицій суч сної стр тигр фії бул дуже спрощеною і недоскон лою (хоч н той ч с схем - олянського бул досить передовою і прогресивною!). ому, зрозуміло, вон д л змогу виділити н тер с х лише три різновікові горизонти лесу ${ }^{3}$. уч сні дослідники виділяють н б г то більше лесових горизонтів $[2 ; 3 ; 7 ; 8$, с. $57 ; 34 ; 37$, с. 42-43, рис. 13 , с. 49 , рис. $14 ; 44$, s. 317 , tab. 36-39] (див. т бл. 3 ).

н чення концепту льних ідей - олянського у вивченні лесів олино- оділля, безперечно, неможливо переоцінити для розвитку суч сної п леогеогр фії, с ме:

- 3 стосув вши нові н той ч с комплексні методи досліджень, учений уперше розділив лесовий покрив олино- оділля н три окремі різновікові горизонти, які відповід ють трьом епох м зледенінь: ст рший лес (риське зледеніння), молодший лес (ф 3 вюрмського зледеніння) і молодший лес (ф з вюрмського зледеніння);

- у ході вивчення лесових покривів ереднього ридністер'я з стосув в комплексний підхід у стр тигр фічному описі лесово-грунтових горизонтів, з лучив різносторонні критерії оцінки вл стивостей т умов формув ння цих відкл дів;

- виділені горизонти лесів сх р ктеризув в викопними флорою т ф уною, зокрем м л коф уною, визн чення якої проводив с мостійно; н підст ві зн йдених рослинних і тв ринних решток спробув в зробити клім тичні реконструкції ч су кумуляції плейстоценових відкл дів н території олино- оділля [30, т бл. 3];

- н підст ві вл сних польових досліджень розвив в теорію еолового походження лесів;

- висловив прогресивну ідею з лучення покривних лесово-грунтових товщ тер с до вирішення проблеми ч су їхнього формув ння і поширення (для долини ністр ); в жливе місце відводив пит нням з ляг ння різновікових лесів н тер с х (теорія “леси і тер си”, яку сьогодні ктивно розвив ють суч сні дослідники плейстоцену оділля);

- уперше переконливо довів, що горизонти лесів поділені бо викопними грунт ми, бо перерв ми в ос дон гром дженні;

- н д в в в жливого стр тигр фічного зн чення горизонт м викопних грунтів; зокрем , н віюв ння лесового м тері лу пов'язув в з холодними і сухими льодовиковими період ми, викопні грунти й перерви в ос дон гром дженні - 3 теплими й вологими міжльодовиковими період ми, що було досить прогресивно н той ч с;

- звернув ув гу н хронологічне відношення лесів до епох покривних зледенінь, н підст ві чого проводив кореляцію лесових відкл дів олино- оділля з моренними відкл д ми хідної вропи т ереднього ридніпров'я;

\footnotetext{
2 . еклич зі спів вт. ( . іренко, . твї̈шиною, . ер сименко, . ожиком, овкоплясом, . д менком, . огуцьким т ін.) створив з г льну стр тигр фічну схему плейстоцену кр їни, що з тверджен [34].

3 ізніше . олянський говорив про н явність н території хідного оділля п'яти лесових горизонтів [31, с. 57].
} 
тр тигр фічн схем кореляції лесово-грунтової серії кр їни

$[2 ; 3 ; 7-9 ; 37$, с. $48-50$, рис. $14 ; 41 ; 44]$

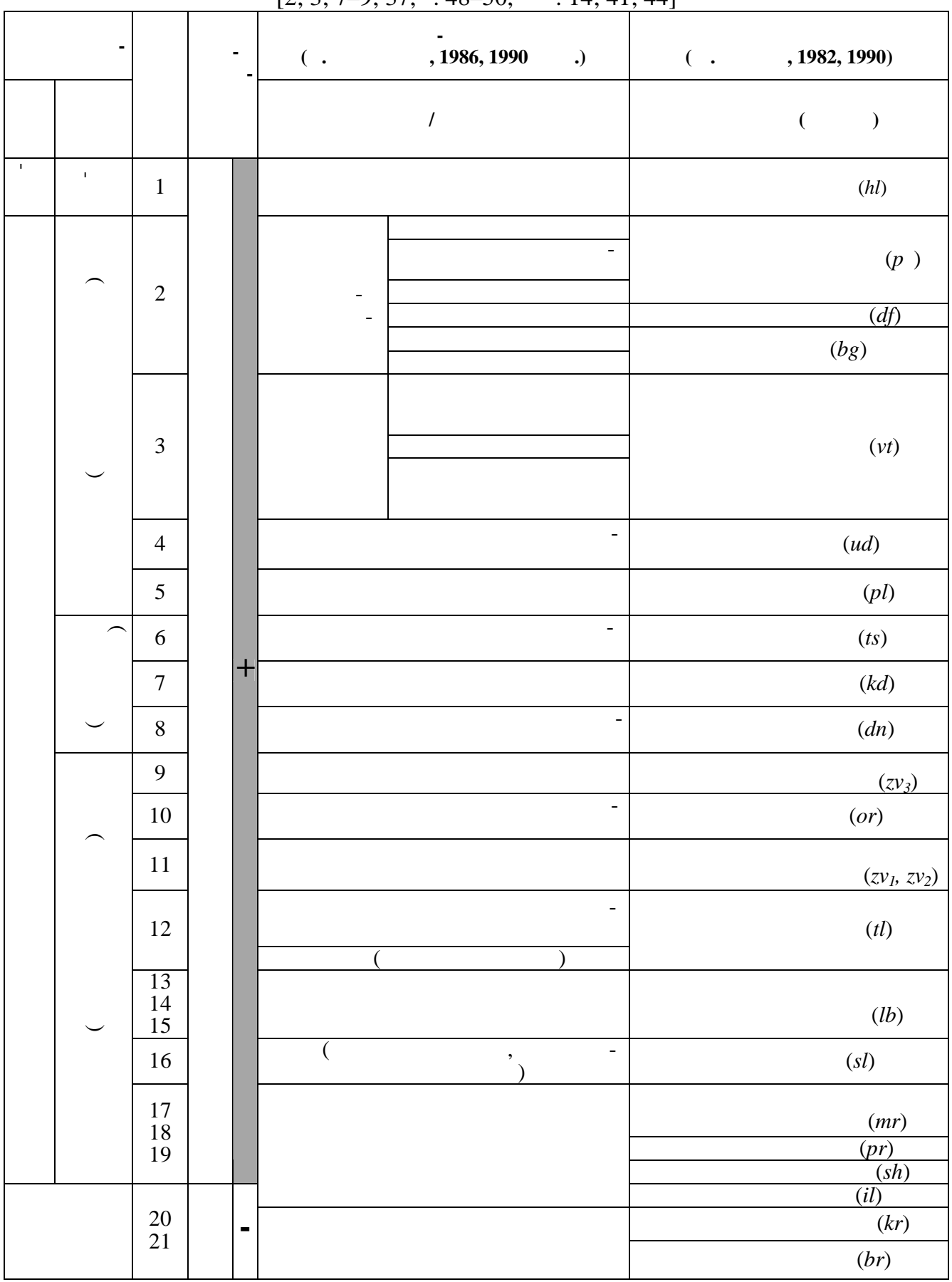


- під ч с стр тигр фічних досліджень плейстоценових відкл дів ереднього ридністер'я відкрив низку стоянок п леолітичної людини; зн хідки культурних ртеф ктів прив'язув в до певних стр тигр фічних горизонтів, що д в ло змогу точніше хронологічно д тув ти як с мі п леолітичні ртеф кти, т к і лесово-грунтові товщі.

голосимо, що перев жн більшість отрим них . олянським висновків не втр тил кту льності й сьогодні. они витрим ли не тільки випробув ння ч сом, й сприяли розвою суч сної п леогеогр фічної н уки.

есово-грунтові товщі н суч сному ет пі досліджень використовують як головний з сіб стр тигр фічного озн чення ч су розгорт ння геологічних, геоморфологічних подій нтропогену. они формув лись поз меж ми плейстоценових зледенінь, тому й з фіксув ли всі зн чні клім тичні події нтропогену. ожен з горизонтів чи то лесів, чи то викопних грунтів відповід є ч су розгорт ння великих п леогеогр фічних подій м терикових зледенінь чи міжльодовиків'їв.

еси є цінним стр тигр фічним м тері лом ще й з тієї причини, що вкрив ють величезні площі й розвинуті в меж х різних геоморфологічних елементів: улоговин, рівнин, н схил х, вододіл х, височин х. тже, стр тигр фічне розчленув ння лесових товщ д є змогу д тув ти ет пи розвитку процесів у меж х величезних і н йрізном нітніших територій.

розрізі нтропогену лицького ридністер'я . огуцький визн чив послідовне чергув ння (знизу вверх) горизонтів лесів т викопних грунтів - сум рно шістн дцять потужних горизонтів (див. т бл. 3).

тр тигр фічні горизонти лесово-грунтової товщі д ють інформ цію не лише про кількість, послідовність розгорт ння великих фізико-геогр фічних ет пів розвитку (п леогеогр фічних подій) території досліджень, яким присвоюють р нг гляці лів чи інтергляці лів, т кож про п леогеогр фічні події дрібнішого р нгу - ст ді ли т інтерст ді ли. ьогодні вже з'ясов но, що фізико-геогр фічні умови в меж х гляці лу чи інтергляці лу з зн в ли окремих невеликих змін, які т кож з фіксов ні у відкл д х, зокрем :

- лесовий горизонт може вмішув ти інтерст ді льні викопні грунти;

- викопні грунти (грунтові комплекси) можуть містити лесові прош рки.

ому суч сні стр тигр фічні схеми четвертинних відкл дів м ють зн чно скл днішу iєp рхію, ніж т , якою послуговув вся у дослідженнях . олянський.

отужність лесового покриву і кількість ярусів похов них грунтів тісно пов'яз ні з рельєфом т віком геоморфологічних елементів території, н яких з ляг є лес.

им д вніш тер с , тим більш потужність ії лесового покриву і тим повніше н ній розвинен ярусність лесової серії. олино- оділлі потужність і ярусність лесово-грунтової серії зі зрост нням бсолютних висот зменшується. еншу потужність лесової товщі дослідники пов'язують з епейрогенічним підняттям цієї ділянки суші під ч с плейстоценового періоду, що супроводжув лося їхнім розмивом.

. морій виділяв для території кр їни три добре вир жені похов ні грунти (дніпровсько-в лд йський - R-W, лихвинсько-дніпровський - M-R i лихвинський M-інтерст ді лу), що простежуються н зн чній території кр їни, похов ний грунт в лд йського (W) інтерст ді лу, н думку вченого, вир жений сл бко. е дослідник повністю пов'язув в із трьом основними льодовиковими епох ми т їхніми ст діями т міжльодовиковими епох ми, визн ченими н території кр їни (вюрмською, риською і міндельською бо в лд йською, дніпровською і окською, відповідно) [19, c. $488-496]$. 
т кож інші, дещо дет льніші стр тигр фічні схеми лесово-грунтової серії плейстоцену, розроблені укр їнськими т з кордонними дослідник ми-четвертинник ми: . екличем, . іренко, . твї̈шиною . ожиком, . ер сименко т ін. [13, 34, 43], . еличком [11, 37], . оліховською [4], принцип побудови яких не відрізняється від зг д них вище схем.

рхеологія. олянський, досліджуючи лицьке ридністер'я, відкрив чим ло стоянок п леолітичної людини. і рештки були т кож цінним м тері лом для з кріплення хронології і з'ясув ння р ціон льної кореляції здобутків ученого з добре вивченими і хронологічно визн ченими відрізк ми плейстоцену ередньої і хідної вропи.

т пи розвитку п леолітичних культур корелюють зі стр тигр фічною схемою відкл дів лицького ридністер'я (т бл. 4).

блиця 4

хем кореляції стр тигр фічних горизонтів верхньоплейстоценових відкл дів теритоpiï лицького ридністер'я з п леолітичними культур ми [41, 44]

\begin{tabular}{|c|c|c|c|c|c|}
\hline \multicolumn{2}{|c|}{$\begin{array}{c}\text { Г льн стр - } \\
\text { Тигр фічн } \\
\text { Шाк Л } \\
\end{array}$} & \multirow{2}{*}{\multicolumn{2}{|c|}{$\begin{array}{l}\text { оризонти і підгоризонти стр ти- } \\
\text { гр фічної схеми верхньоплейстоце- } \\
\text { нових відкл дів території лиць- } \\
\text { кого ридністер'я }\end{array}$}} & \multirow{2}{*}{$\begin{array}{c}\text { леолітичні стоянки } \\
\text { ( } \quad \text { лицьке ридністер'я) }\end{array}$} & \multirow{2}{*}{$\begin{array}{l}\text { рхеологічні } \\
\text { культури }\end{array}$} \\
\hline озділ & Hк & & & & \\
\hline 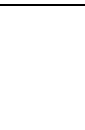 & $\begin{array}{l}5 \\
5 \\
5\end{array}$ & \multicolumn{2}{|c|}{ уч сний грунт } & & $\begin{array}{r}\text { езоліт i } \\
\text { молодші } \\
\text { культури } \\
\end{array}$ \\
\hline \multirow{12}{*}{ 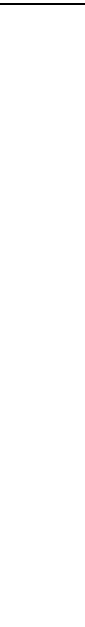 } & \multirow{11}{*}{ 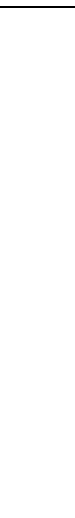 } & \multicolumn{2}{|c|}{ есовий горизонт } & & \multirow{6}{*}{$\begin{array}{c}\text { ізня пор } \\
\text { пізнього п - } \\
\text { леоліту }\end{array}$} \\
\hline & & \multicolumn{2}{|c|}{ ніці льний грунт (кр силівський) } & озино & \\
\hline & & \multicolumn{2}{|c|}{ есовий горизонт } & & \\
\hline & & \multicolumn{2}{|c|}{ ніці льний грунт (рівненський) } & ежигірці, овге, лич & \\
\hline & & \multicolumn{2}{|c|}{ есовий горизонт } & лич & \\
\hline & & \multicolumn{2}{|c|}{ оризонт соліфлюкції } & & \\
\hline & & \multicolumn{2}{|c|}{ убнівський грунт } & & \multirow{2}{*}{$\begin{array}{c}\text { ередня пор } \\
\text { пізнього п - } \\
\text { леоліту } \\
\end{array}$} \\
\hline & & \multicolumn{2}{|c|}{$\begin{array}{c}\text { ижній горизонт } \\
\text { верхньоплейстоценових лесів }\end{array}$} & & \\
\hline & & \multirow{3}{*}{$\begin{array}{c}\text { орохівський } \\
\text { викопний грунто- } \\
\text { вий комплекс }\end{array}$} & оризонт & олодіїв, зупіль (ш р 2) & \multirow{3}{*}{$\begin{array}{c}\text { ння пор } \\
\text { пізнього п - } \\
\text { леоліту }\end{array}$} \\
\hline & & & оризонт & зупіль (ш р 3) & \\
\hline & & & оризонт & & \\
\hline & 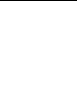 & \multicolumn{2}{|c|}{$\begin{array}{c}\text { ерхній горизонт } \\
\text { середньоплейстоценових лесів }\end{array}$} & & устьє \\
\hline
\end{tabular}

ч с м йже дв дцятилітніх теренових розшуків . олянський відкрив 66 п леолітичних місцезн ходжень (стільки ж, м буть, і п м'яток інших рхеологічних епох) [27, 28, 30, 48, 49]. ільш-менш грунтовні рхеологічні розкопки вели н двох пізньоп леолітичних стоянк $\mathrm{x}$ - исичник х т овосілці- остюковій у ліщицькому р-ні н ернопільщині [33, с. 142]. 
йвідомішою п м'яткою є пізньоп леолітичне поселення исичники, що містилося н невеликому мисі пр вого берег р. ерет, в урочищі овчків. верхньоплейстоценовій товщі лесів тут досліджено три культурні горизонти, верхній і нижній з яких виявились дуже “бідними”. оловний ш р (другий), у якому зн йдено близько 3 тис. крем'яних виробів, з ляг в у “молодшому лесі II” і був д тов ний ориньяцьким ч сом (пізніше це д тув ння спростов но).

ругою п леолітичною стоянкою, яку досліджув в . олянський, $є$ овосілк остюков - он розт шов Н н вододілі ністр і струмк румов, приблизно Н 150 м н д рівнем течії ріки.

озкопки проводили у 1923, 1925, 1926 і 1928 рр. спільно з рхеологом . руковським. глибині $0,70-0,85$ м від суч сної поверхні виявлено сліди прожив ння первісних людей - рештки вогнищ, крем'яні вироби, що дет льно опис ні у спільній публік ції [52]. ронологічні межі п м'ятки визн чені як “преоріньяк”, хоч , н думку пізніших дослідників, для т кого висновку нем є в гомих підст в. зн чимо, що околиці с. овосілки досить ретельно досліджені молодим н уковцем з боку п леогеоморфології т стр тигр фії плейстоценових відкл дів, що д ло йому змогу створити “дилюві льну циклічну схему полудневого оділля” [25, с. 3-24]. я схем м л в жливе зн чення і для періодиз ції п леоліту оділля.

полі дослідник вів дет льні описи розт шув ння п м’яток, визн ч в їхню н лежність до тер с ріки, вивч в зв'язок із х р ктером відкл дів і виявляв приуроченість м тері льних решток до тих чи інших плейстоценових горизонтів, досліджув в культурні ш ри у комплексі із з лишк ми мікро- т м кроф уни, флори тощо [33, с. 142].

уковець $з$ луч в до своїх досліджень учених із суміжних г лузей, зокрем, рхеологів, п леобот ніків, п леозоологів. .олянський т кож і с м н 6 г тьох досліджув них п м'ятк х визн ч в культурну н лежність зн йдених ртеф ктів і види викопних решток м л коф уни.

період 1930-х років н йр нішою стоянкою н терен х ридністер'я бул мустьєрськ п м'ятк сперівці, яку відкрив й досліджув в . олянський. он розміщен н прихиленому до стрімких скель м йд нчику поблизу глибокого ерозійного яру, в урочищі нд торія (околиці однойменного сел ліщицького р-ну н ернопільщині). он досить грунтовно досліджен в геологічному спекті [30] ( рхеологічні м тері ли т к і не були опубліков ні в повному обсязі). к одн 3 н йцік віших і н йр ніших п м'яток середнього п леоліту хідної вропи, вон широковідом в н уковій літер турі [32]. ультурний ш р, що містився під товщею лесових відкл дів, був ч стково розмитий і перевідкл дений ще у плейстоценовий період, одн к, незв ж ючи н це, горизонт виявився досить б г тим н рхеологічні м тері ли, зокрем, викопну плейстоценову ф уну. ут зн йдені з лишки кісток м монт , волох того носорог , зубр , коня, бл городного оленя, вовк т ін. мови з ляг ння ш ру т типологічні озн ки комплексу крем'яних виробів д ли змогу д тув ти його пізньомустьєрським віком [30]. ультурно-історичне місце сперівців не визн чене повністю й дотепер, хоч п м'ятк м $є$ н дзвич йно в жливе зн чення як перше стр тифіков не поселення мустьєрської культури в континент льній кр їні.

осить б г то п м'яток пізнього п леоліту не було досліджено шляхом розкопок. роте зібр ні н поверхні цих п м'яток м тері ли т кож м ють в жливе н укове зн чення для вивчення історії пізньоп леолітичного н селення з ходу кр їни. е т кі місцезн ходження, як икол ївк, убин, он стирок, овге, отівк, итівці, озу- 
линці, оропець, триг нці, ошнів, ріямпіль, ереж ни, уківн т ін. г дки про ці пункти п леоліту можн зн йти у б г тьох н укових пр цях [33].

йв жливішим історичним висновком . олянського є окреслення і всебічн історико-природнич х р ктеристик “ одільсько- есс р бської провінції пізнього п леоліту”, у якій виділено з хідноподільську (70 п м’яток), східноподільську (44 п м'ятки) і південно-східну (22 п м'ятки) групи. г лом у “провінції” н середину 1930-х років було відомо 126 п леолітичних об’єктів (чи не н йбільш концентр ція у вропі), к ртогр фув ння і визн чення хронології яких д ло підст ви для кількох цік вих н укових припущень. окрем , . олянський ув ж в, що первісні мисливці пересув лися вслід 3 т бун ми північних оленів з одних територій н інші (с ме цим він пояснює “одн кові риси” крем'яного інвент рю н величезних простор х вропи). кі пересув ння відбув лися перев жно в “оріньяцький ч с".

ов торською бул т кож думк . олянського про тісний зв'язок п леолітичного н селення оділля з первісними колектив ми центр льноєвропейського регіону. ьогодні ці пит ння розробляе б г то п леолітозн вців як кр їни, т к і з рубіжних кр їн. ожн т кож ск з ти про глибоку н укову інтуїцію дослідник , який н підст ві одного двобічно обробленого н конечник 3 онюшків ( ог тинщин ), т к зв ного солютрейського типу, висловив припущення про вплив “угорського п леоліту”, де т кі н конечники тр пляються серійно, н пізньоп леолітичне н селення (оріньяцькі п м'ятки) оділля. я проблем й нині н суч сному рівні розвитку п леолітичної н уки ст новить зн чний інтерес. осить перспективним н прямом досліджень $є$ положення · олянського про генетичну спорідненість верхньоп леолітичного н селення оділля, олині і олісся [30, 48, 49].

ектонік , ет пи розвитку рельєфу. омплекс досліджень, проведених у лицькому ридністер'ї, д в змогу . олянському зробити кільк висновків про історію геолого-геоморфологічного розвитку території [25]. ередусім простежено різку відмінність у морфології рельєфу, будові четвертинного покриву між обл стю ередк рп тської височини т обл стю олино- одільської височини [30].

леогеогр фічні події відобр жені як у рельєфі, головно у річкових тер с х, т к і у відкл д х - лювії, лес х, викопних грунт х тощо. . олянський розробив схему хронологічної кореляції четвертинних відкл дів т геоморфологічних процесів, що відбув лись н території лицького ридністер'я [30, т бл. 3]. окрем , п леогеогр фічні події, які з фіксов ні у рельєфі, д ли підст ви . олянському провести п леогеогр фічні реконструкції т виокремити три цикли (шість великих ет пів - діб ерозії т кумуляції) розвитку рельєфу, що відповід ло формув нню шести тер с ністр (див. т бл. 5).

уч сними дослідник ми з'ясов но, що кожен з цих великих п леогеогр фічних ет пів скл д ється 3 декількох дрібніших п леогеогр фічних подій, з фіксов них у відкл д х. прикл д, упродовж ч су формув ння п'ятої тер си відбулось кільк змін у процес $\mathrm{x}$ ос дон гром дження - н копичилось три горизонти лесів і дв горизонти викопних грунтів. ідповідно, це кільк с мостійних п леогеогр фічних ет пів, м терикових зледенінь (леси) і м терикових потеплінь (викопні грунти).

ослідники . огуцький т . цишин перший ет п у формув нні передк рп тського фр гмент території лицького ридністер'я пов'язують з розвитком шостої тер си (рівня оєвої). вніший ет п-утворення сьомої тер си ністр т його приток (рівня р сної) - потребує под льшого вивчення. тері лів для його висвітлення вкр й м ло. копичення лювію шостої тер си прип ло н еоплейстоцен - лювій 
тер си у розрізі гвіздя з ляг є нижче межі рюнес- туям (м йже 800 тис. років тому) [41, с. 157-162].

блиця 5

піввідношення ерозійних циклів т геоморфологічних процесів н території лицького ридністер'я (з $[25,30])$

\begin{tabular}{|c|c|c|c|c|}
\hline $\begin{array}{r}\text { бсо- } \\
\text { Лютн } \\
\text { висот } \\
\end{array}$ & $\begin{array}{l}\text { розійні } \\
\text { цикли }\end{array}$ & $\begin{array}{l}\text { еологічні події, } \\
\text { геоморфологічні процеси }\end{array}$ & $\begin{array}{l}\text { рив лість } \\
\text { циклу }\end{array}$ & \begin{tabular}{|c|} 
т дії \\
розв итку \\
рельєфу \\
\end{tabular} \\
\hline нижче & 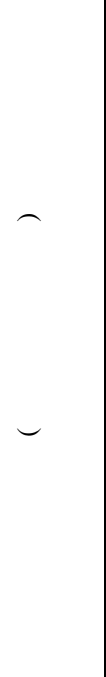 & $\begin{array}{l}\text { відступом льодовиків змінил сь систем } \\
\text { тмосферної циркуляції: суху нтициклон льну } \\
\text { систему льодовикових фенів } 3 \text { мінили вологі } \\
\text { з хідні тл нтичні вітри. івень води у по- } \\
\text { дільських рік х збільшився, лес перест в ку- } \\
\text { мулюв тися. руге тектонічне підняття о- } \\
\text { ділля. } \\
\text { об ерозї̈ - від кінця седимент ції відкл дів } \\
\text { першої тер си і до сьогодні. } \\
\text { об кумуляції- н копичення лювію першої } \\
\text { тер си. } \\
\text { об ерозї - від кінця н віюв ння молодшого } \\
\text { лесу до поч тку седимент ції лювію першої } \\
\text { тер си. } \\
\text { об кумуляції- н копичення лювію другої } \\
\text { тер си і молодшого лесу . } \\
\text { об ерозї̈-від кінця н віюв ння молодшого } \\
\text { лесу до поч тку кумуляції лювію другої } \\
\text { тер си. } \\
\text { об кумуляцї - н копичення лювію третьої } \\
\text { тер си і молодшого лесу . } \\
\text { об ерозії- від кінця н віюв ння ст ршого } \\
\text { лесу до поч тку седимент ції лювію третьої } \\
\text { тер си. }\end{array}$ & 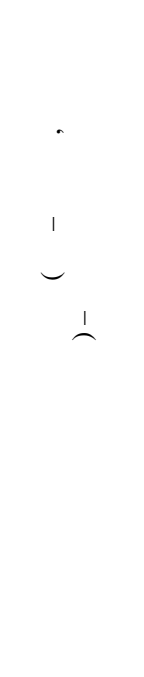 & 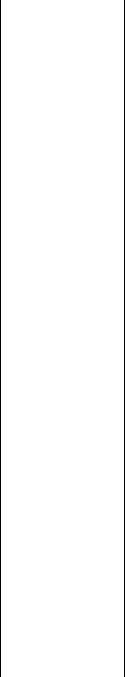 \\
\hline & 焉 & $\begin{array}{l}\text { лім т ст в сухішим т холоднішим. ісля } \\
\text { відступу льодовиків н північ оділля ст ло } \\
\text { територією еолової (лесової) кумуляції, як } \\
\text { зумовил зм'якшення форм рельєфу, що з ли- } \\
\text { шилися після першого циклу норм льної ерозії. } \\
\text { об кумуляцї̈ (умовн ) - н копичення лю- } \\
\text { вію четвертої тер си. } \\
\text { об ерозії (умовн ) - від кінця н віюв ння } \\
\text { ст ршого лесу до поч тку седимент ції лювію } \\
\text { четвертої тер си. } \\
\text { об кумуляції - н копичення лювію п’ятої } \\
\text { тер си і ст ршого лесу. }\end{array}$ & 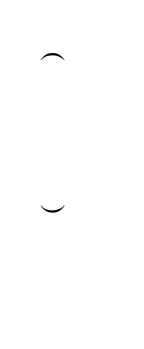 & \multirow{3}{*}{ 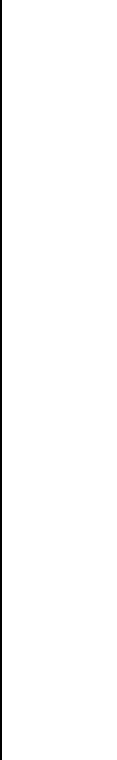 } \\
\hline & \multirow[t]{2}{*}{ 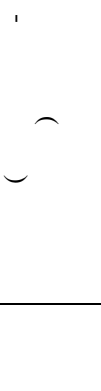 } & $\begin{array}{l}\text { ерше тектонічне зрушення оділля. ідняття } \\
\text { оділля н 60-70 м. ормув ння системи } \\
\text { невисоких і численних нтиклін бескидського } \\
\text { н прямку. одільські ріки прорізують плиту т } \\
\text { “спих ють” ністер н південь. } \\
\text { об ерозї̈ - від кінця седимент ції відкл дів } \\
\text { шостої тер си до поч тку седимент ції відкл - } \\
\text { дів п'ятої тер си. }\end{array}$ & 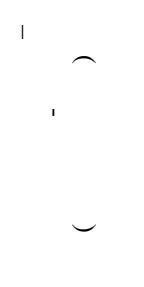 & \\
\hline вище & & $\begin{array}{l}\text { об кумуляції - н копичення лювію шостої } \\
\text { тер си. }\end{array}$ & $\begin{array}{l}\text { 胥 } \\
\stackrel{0}{0} \\
.\end{array}$ & \\
\hline
\end{tabular}


одо реконструкції фізико-геогр фічних умов, які п нув ли протягом цього п леогеогр фічного ет пу, то вони відтворені н уковцями головно н підст ві н лізу лювію, оскільки суб ер льні відкл ди (леси, викопні грунти) суттєво перетворені вторинними процес ми. р нулометричний скл д, ступінь обк т ності, сортов ності люві льного гр війно-г лечникового м тері лу свідч ть про зн чну тр нспортув льну зд тність ністр т його приток. ожливо, це пов'яз но з доволі теплим, вологим клім том (б г то оп дів - зН чн водність рік - зН чн тр нспортув льн зд тність водних потоків) бо з ктивними тектонічними підняттями рп т, ередк рп ття (тектонічні підняття - зрост ння ухилу русл - збільшення швидкості течії - зрост ння тр нспортув льної зд тності потоку) чи з обом чинник ми одноч сно.

ругий п леогеогр фічний ет п, н думку цих дослідників i $\mathrm{H}$ перекон ння

олянського, пов’яз ний з розчленув нням шостої тер си, формув нням ерозійного уступу до п'ятої тер си і н копиченням люві льної товщі п’ятої тер си. різ ністр , його приток у поверхню шостої тер си зумовлений передусім розвитком висхідних тектонічних рухів у ередк рп тті т н оділлі. либин врізу досяг $є 35$ м. ормув лися перші контури ністерського к ньйону. еріод розгорт ння цих геоморфологічних подій досить трив лий, він охопив: при зовський, м ртоноський, сульський, лубенський і ч стину тилігульського ч су - приблизно 700-530 тис. років тому, бо протягом 21-12 ізотопно-кисневих ст дій ( ). чевидно, що ч стин цього ет пу прип д л н процес формув ння ерозійного уступу до п’ятої тер си (вріз ння ністр з приток ми у шосту тер су), можливо, між 700-620 (?), чи 502 (?) тис. років тому, тобто протягом 21-15 (?) чи $13(?)$. ід ч с іншої ч стини ет пу н копичув вся лювій п’ятої тер си, це було у проміжку між 620-530 тис. років тому, бо протягом 15 (13 ?)12 . ізико-геогр фічні умови цього ет пу вкр й мінливі: від теплих інтергляці льних до дуже холодних перигляці льних. міни були яскр во вир женими циклічними: холодний (лесовий горизонт у розрізі гвіздя) при зовський ч с, теплий (викопний грунт типу з гвіздя) м ртоноський ч с, знову холодний (лесовий горизонт у розрізі

гвіздя) сульський ч с, теплий (викопний грунт типу солотвин у розрізі гвіздя і русловий гр війно-г лечниковий м тері л тер си у личі) лубенський ч с і холодний (лесовий горизонт у розрізі гвіздя і перигляці льний лювій у розрізі лич) тилігульський ч с. . огуцький т . цишин ув ж ють, що вріз ння відбулось т кож у поверхню одільської височини. тже, розрізнені фр гменти люві льного гр війног лечникового м тері лу н межиріччі орон - ністер н копичув лися щон йменше в еоплейстоцені, тобто вони корелюють 3 шостою тер сою ністр у ередк рп тті.

оч морфометричні критерії - бсолютні висоти, відносні відмітки розрізів стосовно русл річки - д ють підст ви говорити про н копичення цього м тері лу у д вніший (пліоценовий) ч с (сьом тер с ).

ретій ет п - ет п розчленув ння п'ятої тер си, формув ння ерозійного уступу до четвертої тер си і н копичення лювію цієї тер си. либин врізу досяг є 10-12 м, м ксимум - до 15 м. і процеси розгорт лися протягом теплого (луцький викопний грунт у розріз х гвіздя, лич) з в дівського, холодного (лесовий горизонт у розрізі

лич) дніпровського i, н решті, теплого (коршівський викопний грунтовий комплекс у розріз х гвіздя, лич т лювію тер си у ріямполі) к йд цького ч сів. искусійним суч сні дослідники вв ж ють пит ння ч су кумуляції лювію тер си: бо кінець дніпровського-поч ток к йд цького ч су, бо лише к йд цький ч с. ст ннє припущення, н погляд . огуцького т . цишин , є ймовірнішим [44]. бсолютній (геохронологічній) шк лі ці події розгорт лися в т ких меж х: вріз ння ністр - між 
430-330 тис. років тому, тобто 11-8 ; кумуляція лювію - 330-230 тис. років тому, тобто 7

ід ч с четвертого ет пу розгорт лися процеси вріз ння ністр 3 приток ми в четверту тер су, що досяг є 7-10 м. різ прип в н теплий (коршівський викопний грунтовий комплекс у розріз х гвіздя, лич, ріямпіль) к йд цький ч с, в холодний (лесові горизонти у розріз х гвіздя, лич, ріямпіль) тясминський ч с відбувся процес кумуляції лювію третьої тер си. бсолютних ч сових меж х це, відповідно, 230-210 тис. років тому (7 ) і 210-130 тис. років тому (6 ).

п’ятому ет пі, 3 дослідженнями . огуцького т . цишин , знову розгорнулися процеси вріз ння ністр з приток ми, ле вже у третю тер су, вироблення ерозійного уступу до другої тер си і н копичення лювію другої тер си. либину врізу визн чити достовірно досить скл дно, оскільки у олодієві цоколь піднім ється н висоту 1,2 м н д руслом р. ивк, в озиній він витрим ний н рівні води у руслі ністр в межень. озчленув ння прип ло н 3 вершення холодного (лесові горизонти у розріз х лич, ріямпіль) тясминського ч су, н копичення лювію - н теплий (викопний грунт у розріз х лич, ріямпіль, олодіїв) прилуцький ч с. ідповідно, це 210-130 тис. років тому (6 ), 130-77 тис. років тому (5 ). оді ж розпоч лося з селення лицького ередк рп ття п леолітичною людиною (стоянки у зуполі, личі).

, н решті, ост нній, шостий великий п леогеогр фічний ет п супроводжув вся розгорт нням процесів ерозійного розчленув ння другої тер си, виробленням уступу до першої тер си глибиною м ксимум до 1,2 м і н копиченням лювію першої тер си т серії різновисотних з пл вних рівнів. і геоморфологічні процеси розгорт лися протягом ост нніх 77 тис. років, тобто 1-4

пропонов н . огуцьким т . цишиним суч сн схем п леогеогр фічних ет пів розвитку території лицького ридністер'я дет льніш від схеми, розробленої

. олянським, одн к побудов н н т кі в жливі тенденції: трив лість ет пів суттєво зрост є, дет льність відтворення фізико-геогр фічних умов знижується з відд ленням ет пів (геоморфологічних подій) від суч сної епохи. меж х кожного з шести ет пів є досить чіткі критерії для виокремлення дрібніших п леогеогр фічних подій - це горизонти викопних грунтів і лесові горизонти.

зн чимо, що сфер н укових інтересів . олянського не бул обмежен лише територією лицького ридністер'я, хоч с ме тут він проводив більшість польових досліджень, результ ти яких ст ли основою под льших н укових ідей т гіпотез, що Зн йшли розвиток у суч сній н уці. . олянський проводив т кож дослідження н оліссі, пр цюючи в юро меліор ції олісся. ін вивч в тер си центр льної ч стини олісся, їхнє відношення до процесів торфоутворення в цьому регіоні $[50,51], \quad$ т кож досліджув в м л коф уну. чений опис в 88 видів молюсків, 24 з яких були р ніше невідомими для території хідного олісся [29].

е одн пр ця . олянського стосується хронології п леолітичної стоянки в c. ур вк, що н ернігівщині, т р нньоплейстоценових тер с ніпр [26, с. 1-8]. цій н уковій пр ці дослідник про н лізув в висновки різних учених, які визн ч ли вік тер с ніпр , що сформув лися у р нньому плейстоцені, т кож ч с прожив ння п леолітичної людини н цій території. ін відмітив н укові здобутки к д. . ізниченк т проф. . рокос під ч с дослідження лесон гром дження в різні ч сові відтинки 
плейстоцену, що д ло змогу вперше корелюв ти плейстоцен ередньої і хідної вропи з плейстоценом хідної вропи.

еякі дослідження . олянський проводив н території суч сної олдови - тодішньої есс р бії, н пр вому березі ністр [28, с. 1-14]. публік ції втор висловив критичні з ув ження щодо висновків проф. . лоров $\mathrm{T}$ румунських н уковців . мброжевич т . отез про стр тигр фічне положення лесів т хронологічні межі т ких стоянок, як “... ізля- еджимов , орм нь і р б ни”.

уков обізн ність т дослідницьк цік вість . олянського відкрил перед ним дорогу у невичерпний т прив бливий світ пізн ння, тому “... ост ється проте одн дорог , це - пеляція до терену, пеляція до цего одинокого, пр вдивого і невичерп ного джерел всякого пізн ння і всіх в ртісних синтез" [30, с. 2]. кими н ст нов ми у щоденній пр ці керув вся - олянський, що, м буть, і сприяло отрим нню н лежних дослідницьких висновків.

ро в гомість і визн ння н укових здобутків . олянського у г лузі геоморфології і п леогеогр фії свідчить той ф кт, що XVI кр їнсько-польський семін р “ йд вніші леси оділля і окуття: проблеми генези, стр тигр фії, п леогеогр фії”, який відбувся 2009 р., т кож вид ний до нього збірник н укових пр ць [23], присвячені цьому визн чному досліднику “полудневого оділля". я подія, до того ж, збігл ся в ч сі 3 80-ю річницею виходу в світ всебічного т глибокого моногр фічного дослідження . олянського “ одільські етюди: тер си, леси т морфольогія лицького оділля н д ністром”, про що теж з зн чено у р мк х міжн родного семін ру. е вип дково, місце проведення польового семін ру - смт к л - одільськ орщівського p-ну ернопільської обл. - рідний т близький для вченого $\mathrm{p}$ йон досліджень.

ідомий укр їнський рхеолог . стерн к 3 з слуги вченого в г лузі рхеології н зв в . олянського “б тьком з хідноукр їнського п леоліту” [24].

ед рм суч сні н уковці вв ж ють . олянського гідним носити високе зв ння ослідник, незв ж ючи н ті життєві обст вини, що змусили молодого мбітного н уковця покинути рідну кр їну й емігрув ти до д лекої л тино мерик нської держ ви. ргентині учений, не покл д ючи рук, н тхненно пр цюв в, досліджув в геологічну будову нд, $з$ що суч сний ргентинський геолог міліо онз лес і з з служено н зв в . олянського “б тьком суч сної геоморфології ргентини” [42].

1. $\quad$ ббот-де- рни . еологическія изследов нія, произведенныя въ 1868 году въ губерніяхъ іевской, одольской и олынской / . рбот-де- рни // п. мпер торского .- етерб. минер л. об-в . тор я серия. - 6., 1872. - . 7. - .40-72.

2. огуцкий . . нтропогеновые покровные отложения олыно- одолии / . . огуцкий // нтропогеновые отложения кр ины. - иев : ук. думк , 1986. - . 121-132.

3. огуцкий . . сновные п леокриогенные эт пы плейстоцен юго-з п д осточновропейской пл тформы / . . огуцкий // етвертичный период : методы исследов ния, стр тигр фия и экология. ез. V сесоюз. совещ. - . 1. ллинн, 1990. - . 65-66.

4. олиховск я . . волюция лессово-почвенной форм ции еверной вр зии / . . олиховск я. - . : зд-во оск. ун-т , 1995. -268 с.

5. онд рчук . . кономерности р спростр нения лёссовой форм ции и принципы её стр тигр фического подр зделения / . . онд рчук // тери лы по четвертичному периоду кр ины ( VII конгрессу еждун родной ссоци ции по изучению четвертичного период (INQUA)). иев : ук. думк , 1965. - .9-29.

6. еклич . . сновні ет пи розвитку річкових долин / . . еклич // еоморфологія річкових долин кр їни. - . : ук. думк , 1965. - .7-26. 
7. еклич . . сновы п леол ндш фтоведения / . . еклич. - иев : ук. думк , 1990. 192 c.

8. еклич . . леоэт пность и стр тотипы почвенных форм ций верхнего к йнозоя / . . еклич. - иев : ук. думк , 1982. - 208 с.

9. еклич . . тр тигр фия лессовой форм ции кр ины и соседних стр н / . . еклич. иев : ук. думк , 1968. - 238 с.

10. еклич . . т пы обр зов ния позднек йнозойских речных долин кр ины. ечные системы и мелиор ция / . . еклич. - овосибирск : зд-во , 1977. - .1. - .23-26.

11. еличко . . волюция почвообр зов ния в плейстоцене / . . еличко, . . орозов // ноголик я геогр фия. звитие идей . . ер симов (к 100-летию со дня рождения). - . : ов-то н уч. изд ний , 2005. - .65-75.

12. иржиківський. еологічн м п кр їни. л ншети V -6 і V -6 ( ддністрянщи-

н : огилів- мпіль) / . иржиківський. - . : кр. геолого.-розв. трест, 1933. -226 с.

13. ер сименко . . озвиток зон льних л ндш фтів четвертинного періоду н території кр їни : втореф. дис. ... Д-р геогр. н ук/ . . ер сименко. - ., 2004. - 40 с.

14. офштейн . . еотектонік і морфогенез ерхнього ридністров'я / . . офштейн. - . : ид-во , 1962.- 132 с.

15. офштейн . . еотектоник п дной олыно- одолии / . . офштейн. - иев : ук. думк , 1979. - 156 с.

16. емедюк . . етвертинні відкл ди / . . емедюк // рирод в но- р нківської обл сті. - ьвів : ищ шк., 1973. - .25-31.

17. в нов . . еология и п леогеогр фия стоянки орм нь $\mathrm{V}$ н общем фоне геологической истории к менного век реднего риднестровья/. . в нов // ногослойн я п леолитическ я стоянк орм нь V. - . : ук у 1977. - .126-181.

18. в нов . . еоморфология и п леогеогр фия риднестровья в п леолите / . . в нов // рирод и р звитие первобытного обществ н территории вропейской ч сти _ . - . : ук , 1969. - . .111-119.

19. морій . . етвертинні відкл ди кр їнської / . . морій. - . : ид-во иїв. унту, 1961. - . . $-550 \mathrm{c.}$

20. $р$ вчук . . еоморфологія ередк рп ття / . . р вчук. - ьвів : ерк тор, 1999. $188 \mathrm{c}$.

21. рокос . . р ткий очерк четвертичных отложений кр ины / . . рокос // юл. оск. о-в испыт т. природы. тд. геологии. - 1926. - ып. 4. - . 214-264.

22. рокос... тері ли до х р ктеристики четвертинних покл дів східної і південної кр їни / . . рокос // тері ли дослідження грунтів кр їни. екція грунтозн вств . - рків, 1927. - .9. - ип. 5. - . 1-325.

23. йд вніші леси оділля і окуття: проблеми генези, стр тигр фії, п леогеогр фії. бірник н укових пр ць (до XVI укр їнсько-польського семін ру. к л - одільськ, 13-16 вересня 2009 р.). - ьвів : $\quad$ ім. . р нк , 2009. - 246 с.

24. стерн $\kappa$. і, що розкрили підземний рхів кр їни (п м'яті вид тних рхеологів кр їни) / . стерн к // ерем. роблеми укр їнської культури. кр їн н досвітку історії. - етройт, 1976. - . 7-12.

25. олянський .. еольогічно-морфольогічні поміч ння в р йоні овосілки остюкової ( ліщики) і ділюві льн циклічн схем полудневого оділля / . . олянський // б. фізіогр. комісії .-1925. - ип. 1. - .3-24.

26. олянський . . в в ги до хронології п леолітичної стоянки в ур вці т молодоплейстоценських тер с середнього ніпр / . . олянський // ідбитк зі зб. фізіогр. комісії _ . 1932. - ип. 4-5. - . 1-8.

27. олянський . . ові рхеольогічні зн хідки з личини / . . 1928. - . .149. - . .1-36.

28. олянський . . ові пр ці про плейстоцен есс р бії / . . олянський // ідбитк зі зб. фізіогр. комісії $\quad .-1927 .-$ ип. $2 .-$. $1-14$. 
29. олянський . . тері ли до пізн ння м л коф вни з хідного олісся / . . олянський // ідбитк зі зб. фізіогр. комісії . . 1932. - ип. 4-5. - . 1-19.

30. олянський .. одільські етюди: тер си, леси і морфольогія лицького оділля н д ністром / . олянський // б. м тем.-природ.-лік р. секції . 1929. - . 20. - 191 с.

31. олянський . . еологія / . . олянський // еогр фія укр їнських і сумежних земель : . 1: г льн геогр фія [ пр ц. і зред. . убійович]. - ьвів : кр. ид вн. н-т, 1938. .27-64.

32. итник . . іля витоків формув ння п леолітичної н уки в кр їні ( . олянський) / . . итник // тері ли і дослідження з рхеології рик рп ття і олині. ост ті укр їнської рхеології. - ьвів, 1998. - ип. 7. - . 16-20.

33. итник . рій олянський - перший дослідник 3 хідноукр їнського п леоліту / . итник // рхеологія. - ., 2003. - ип. 1. - . 140-144.

34. тр тигр фическ я схем четвертичных отложений кр ины / [ . . еклич, . . иренко, твиишин и др.] // тр тигр фические схемы ф нерозоя и докембрия кр ины. - иев : ос. ком. геологии кр ины, 1993. -40 с., 8 т бл.

35. оменюк. рій олянський - дослідник тер с ністр / . оменюк // існ. ьвів. ун-ту. ер. геогр. - 2010. - ип. 38. - . 340-356.

36. оменюк . ослідження лесів олино- оділля - н ріжний к мінь н укових пошуків рія олянського / . оменюк // існ. ьвів. ун-ту. ер. геогр. -2011. - ип. 39. - . 342-363.

37. рофимов . . ёссовый покров емли и его свойств / [ . . рофимов, . . лыков , . . олиховск я и др.]; под ред. . . рофимов . - . . зд-во оск. ун-ту, 2001. - 464 с.

38. нцер . . ллювий р внинных рек умеренного пояс и его зн чение для позн ния з кономерностей строения и формиров ния ллюви льных свит / . . нцер // p. н-т геол. н ук . ер. геол. - 1951. - ып. 135. - . 1-274.

39. цищин . . еоморфологічн будов долини ністр у меж х ередк рп ття : втореф. дис. ... к нд. геогр. н ук / . . цишин. - ьвів, 2001. - 18 с.

40. цишин . . ореляція тер с ністр у меж х ередк рп ття з основними стр тигр фічними горизонт ми лесово-грунтової серії олино- оділля / . . цишин // уч сні проблеми i тенденції розвитку геогр фічної н уки : м тері ли міжн р. конф. до 120-річчя геогр фії у ьвів. ун-ті (24-26 вересня 2003 р.). - ьвів, 2003. - . 285-287.

41. цищин. . етоди дослідження четвертинних відкл дів: н вч. метод. посібник / . . цишин, . . митрук, . . огуцький. - ьвів : ім. . p нк , 2009. - 177 с.

42. Díaz E.F.G. Geomorphology in Argentina / Emilio F. González Díaz / The Evolution of Geomorphology : a Nation by Nation Summary of Development / [Ed. by H.J. Walker and W.E. Grabau]. Chichester; New York : Wiley, 1993. - P. 19-27.

43. Gozhic P. Quaternary stratigraphy / [P. Gozhic, Zh. Matviishina, N. Gerasimenko et al.] // The Ukraine Quaternary explored: the Middle and Upper Pleistocene of the Middle Dnieper area and its importance for the East-West European correlation. SEQS 2001 conf. Excursion guide. - Kyiv, 2001. P. 8-11.

44. Lessy i paleolit Naddniestrza halickiego (Ukraina) / Studia geologica Polonica / [Pod red. T. Madeyskiej]. - Kraków, 2002. - Vol. 119. - Cz. III. - 391 s.

45. Polanskyj G. Bericht / G. Polanskyj // Sitzber. Der Mat.-naturw.-arztl. Sekt. D. Ševčenko Ges. 1927. - Heft 5. - S. 9-10.

46. Polanskyj G. Lessy warstwowane w świetle archeologicznych badań Ludwika Sawickiego / G. Polanskyj // Nadbitka z Wiadomości Archeologicznych. - Warszawa, 1928. - T. 10. - S. 1-12.

47. Polanskyj G. Loess en Podolie et son valeur pour la stratigrafie et morphologie / G. Polanskyj // II Zjazd słowiańskich geografów i etnografów w Polsce. - 1927. - S. 1-2.

48. Polanskyj G. Neue Palaolithithstationen Podoliens / G. Polanskyj // Sitsber. Der Mat.-naturw.-arztl. Sek. D. Ševčenko Ges. - 1927. - Heft 7. - S. 6.

49. Polanskyj G. Rekonstruktion der geographischen Verhältnisse des Jungpaläolithikums der podolisch-bessarabischen Provinz / G. Polanskyj // ідбитк з “ р ць геогр фічної комісії ”. ьвів, 1936. - ип. 1. - .3-23. 
50. Polanskyj G. Staroaluwjalny taras Polesia i jego stanowisko w historii zatorflenia / G. Polanskyj // Odbitka z wydawnictwa: Postęp prac przy Meljoracji Polesia (Sprawozdanie za lata 1931-1932). Brześ nad Bugiem, 1933. - S. 1-10.

51. Polanskyj G. Stratygrafja dyluwjum i tarasy centralnego Polesia / G. Polanskyj // Odbitka z wydawnictwa: Postęp prac przy Meljoracji Polesia (Sprawozdanie za lata 1931-1932). - Brześ nad Bugiem, 1933. - S. 11-16.

52. Polanskyj G. Die erste Paläolithstation in Nowosilka-Kostiukowa (Podolien)/ G. Polanskyj, S. Krukowski // б. м тем.-природ.-лік р. секції .-1926. - .25. 23 с. (Separatabdruck).

m ття: н дійшл до редколегії 08.11.2011 прийнят до друку 22.11.2011

\section{INFLUENCE OF SCIENTIFIC IDEAS OF YURIY POLIANS'KYI ON THE DEVELOPMENT OF GEOMORPHOLOGY AND PALEOGEOGRAPHY IN UKRAINE (to 120-years anniversary of the day of birth of Yu. Polians'kyi)}

\section{O. Tomeniuk}

Ivan Franko National University of Lviv, P. Doroshenko St., 41, UA - 79000 Lviv, Ukraine, e-mail:prostolena.87@mail.ru

The article is dedicated to description of major scientific achievements of outstanding Ukrainian paleogeographer, geomorphologist and geologist Prof. Yuriy Polians'kyi. The influence of his scientific ideas on the development of modern geomorphology and paleogeography in Ukraine is analyzed. Special attention is paid to the study of loess deposits and development of terrace horizons on the territory of Dniester region. Results of paleogeographic, geomorphological, archaeological, tectonic exploration of the region carried out by modern researchers are presented too. For the most part of these results are the development of scientific ideas of Yuriy Polians'kyi.

Key words: floodplain terrace, alluvium, loess, fossil soils, glaciations, geological and geomorphological researches, Pleistocene, Paleolithic, Dnister River, Volhyn-Podillia region.

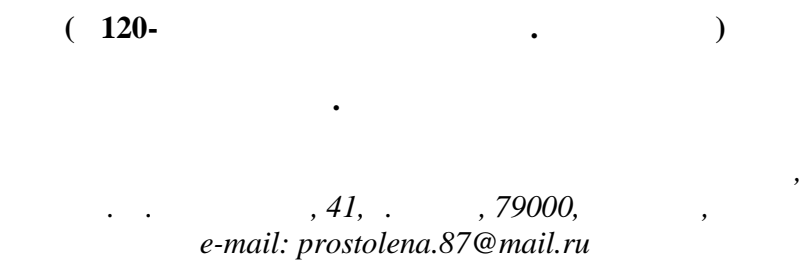

черчено гл вные исследов тельские достижения укр инского п леогеогр ф , геоморфолог , геолог проф. рия олянского. ро н лизиров но влияние его н учных идей н современных геоморфологии и п леогеогр фии в кр ине. ольшое вним ние уделено изучению лессов и р звитию терр совых уровней н территории лицкого риднестровья. ссмотрено новейшие результ ты п леогеогр фических, геоморфологических, рхеологических, тектонических исследов ний этого регион современными исследов телями. большинстве эти результ ты - р звитие идей . олянского.

лючевые слов : н дпойменн я терр с, ллювий, лессы, ископ емые почвы, оледенение, геолого-геоморфологические исследов ния, плейстоцен, п леолит, нестр, олыно- одолия. 